\title{
Angiosarcoma, porphyria cutanea tarda, and probable chloracne in a worker exposed to waste oil contaminated with 2,3,7,8-tetrachlorodibenzo-p-dioxin
}

\author{
Rob McConnell, Kern Anderson, William Russell, Karl E Anderson, Richard Clapp, \\ Ellen K Silbergeld, Philip J Landrigan
}

\begin{abstract}
A worker developed angiosarcoma, porphyria cutanea tarda, and skin lesions characteristic of mild chloracne. About 10 years earlier he had been employed at a truck terminal in Saint Louis, Missouri, at a time when it was sprayed with waste oil contaminated with 2,3,7,8-tetrachlorodibenzo-p-dioxin (TCDD). The occurrence of these three rare conditions in a single exposed worker supports the aetiological relation between environmental exposure to TCDD and the subsequent development of soft tissue sarcoma and porphyria cutanea tarda.
\end{abstract}

(British Fournal of Industrial Medicine 1993;50:699-703)

Knowledge of the toxic effects of 2,3,7,8-tetrachlorodibenzo-p-dioxin (TCDD) in humans has resulted primarily from clinical and epidemiological studies of workers exposed during the manufacture of chlorinated phenols or as the result of explosions and industrial accidents. It is known that TCDD causes chloracne. ${ }^{1}$ It causes a syndrome resembling porphyria cutanea tarda in animals and is a suspected cause of some cases of this in humans. It

Division of Environmental and Occupational Medicine, Mount Sinai School of Medicine, New York 10029, USA

R McConnell, P J Landrigan

10475 Reading Road, Cincinnati, Ohio 45241, USA

$\mathrm{K}$ Anderson

PO Box 030100, Fort Lauderdale, Florida 33303, USA

W Russell

Division of Nutrition, University of Texas Medical Branch, Galveston, Texas 77550, USA

$\mathrm{K}$ E Anderson

JSI Center for Environmental Health Studies, Boston, Massachusetts 02111, USA

R Clapp

Program in Toxicoloy, University of Maryland, Baltimore, Maryland 21201, USA

E K Silbergeld has also been implicated as a cause of toxic hepatitis, peripheral neuropathy, neuropsychiatric disease, increased susceptibility to infection, abnormal lipid metabolism, and damage to the endocrine, gastrointestinal, and cardiovascular systems. ${ }^{2}$ Minute doses of TCDD are carcinogenic in rodents. ${ }^{3}$ In humans, TCDD has been implicated as a cause of soft tissue sarcoma and malignant lymphoma in some (but not all) epidemiological studies. ${ }^{2}$ Although no occupational exposure standard exists for TCDD, the National Institute for Occupational Safety and Health (NIOSH) has recommended that TCDD be regarded as a potential occupational carcinogen, "that occupational exposure to TCDD be controlled to the fullest extent feasible, and that decontamination measures be used for TCDD contaminated work environments." 4

In Missouri in the early 1970 s, oil contaminated with TCDD was used for dust control on roads at several residential and commercial sites. At some sites, animal deaths and acute illness resulted among exposed persons. ${ }^{5}$ Evaluation of workers from the production plant where the TCDD originated and of residents of the contaminated communities showed raised TCDD concentrations in adipose tissue. ${ }^{6}$ Cell mediated immunity was depressed. ${ }^{7}$ Mean urinary porphyrin concentrations and liver enzyme activities were increased among persons in the exposed community, and these increases were attributed to subclinical hepatotoxic effects.

In this communication we report the case of a worker previously exposed in Missouri to oil contaminated with TCDD, who subsequently developed a soft tissue sarcoma, porphyria cutanea tarda, and probable chloracne. The preliminary evaluation of this case has been reported elsewhere. ${ }^{8}$

\section{Case description}

A 59 year old white male truck driver was in good health until the summer of 1981, when he saw his 
family physician for a rash that had appeared in areas of his body that were exposed to the sun. The rash resolved without specific treatment. During the subsequent summer he experienced blistering and increased hair over the dorsa of his hands. Biopsy of a bulla revealed a subepidermal blister with moderately intense perivascular lymphocytic infiltrate in the underlying superficial dermis, consistent with porphyria cutanea tarda. A laboratory evaluation (table) confirmed the diagnosis of porphyria cutanea tarda. In particular, urinary uroporphyrin, 7-carboxylate porphyrin, and faecal isocoproporphyrin were noticeably increased. As expected in this disease, plasma porphyrins were increased and urinary $\delta$-aminolevulinic acid and porphobilinogen were normal. A liver and spleen scan showed a normal sized liver. There was mild inhomogeneity in distribution of sulphur colloid

Results of laboratory measurements related to porphyria in the patient

\begin{tabular}{|c|c|c|}
\hline Measurement & Patient & $\begin{array}{l}\text { Normal range or } \\
\text { pattern }\end{array}$ \\
\hline $\begin{array}{l}\text { Total urinary } \\
\text { porphyrins } \\
\text { (nmol/24 h) }\end{array}$ & 3432 & $0-300$ \\
\hline $\begin{array}{l}\text { Chromatographic } \\
\text { pattern }\end{array}$ & $\begin{array}{l}\text { Uroporphyrin 1885; } \\
\text { 7-carboxylate } \\
\text { porphyrin 1224; } \\
\text { 6-carboxylate } \\
\text { porphyrin } 98 ; \\
\text { 5-carboxylate } \\
\text { porphyrin 58; } \\
\text { coproporphyrin } 37 .\end{array}$ & $\begin{array}{l}\text { Predominantly } \\
\text { coproporphyrin }\end{array}$ \\
\hline $\begin{array}{l}\text { Urinary } \delta \text { - } \\
\text { aminolevulinic } \\
\text { acid }(\mathrm{mg} / 24 \mathrm{~h})\end{array}$ & $2 \cdot 5$ & $0-7$ \\
\hline $\begin{array}{l}\text { Urinary } \\
\text { porphobilinogen } \\
(\mathrm{mg} / 24 \mathrm{~h})\end{array}$ & $0 \cdot 7$ & $0-4$ \\
\hline $\begin{array}{l}\text { Plasma } \\
\text { porphyrins }(\mu \mathrm{g} / \mathrm{dl})\end{array}$ & $17 \cdot 7$ & Undetectable \\
\hline $\begin{array}{l}\text { Total faecal } \\
\text { porphyrins (nmol/g } \\
\text { dry weight) }\end{array}$ & $g^{149}$ & $0-100$ \\
\hline $\begin{array}{l}\text { Chromatographic } \\
\text { pattern (in } \\
\text { decreasing } \\
\text { amounts) }\end{array}$ & $\begin{array}{l}\text { Isocoproporphyrin, } \\
\text { protoporphrin, } \\
\text { coproporphyrin, } \\
\text { 7-carboxylate } \\
\text { porphyrin, } \\
\text { 6-carboxylate } \\
\text { porphyrin, } \\
\text { 5-carboxylate } \\
\text { porphyrin. }\end{array}$ & $\begin{array}{l}\text { Protoporphyrin, } \\
\text { coproporphyrin. }\end{array}$ \\
\hline $\begin{array}{l}\text { Erythrocyte } \\
\text { uroporphyrinogen } \\
\text { decarboxylase } \\
(\mathrm{nmol} / \mathrm{ml} / \mathrm{h})\end{array}$ & 87 & $81.9(18 \cdot 1)^{\star}$ \\
\hline \multicolumn{3}{|c|}{ 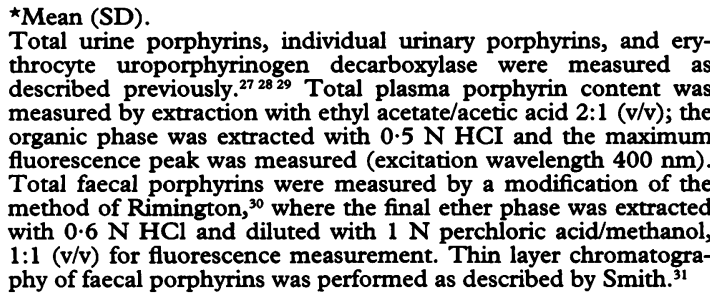 } \\
\hline
\end{tabular}

with mild shift to the spleen, consistent with mild hepatocellular disease. Liver function tests and liver enzymes were normal, although the patient previously had abnormal liver enzymes in 1981 ( $\gamma$-glutamyl transferase $75 \mathrm{IU} / 1$ (normal 0-65), alanine aminotransferase $76 \mathrm{IU} / 1$ (normal $0-45$ ), aspartartate aminotransferase $36 \mathrm{IU} / 1$ (normal $0-41$ ). The patient's symptoms improved with phlebotomy, cessation of his previous weekly consumption of one case of beer, and avoidance of sun, although hypertrichosis persisted and spread to his face, and occasional bullae recurred. Blood uroporphyrinogen decarboxylase was normal in the patient (table), as well as in six of his first degree relatives. There was no family history of porphyria cutanea tarda or inborn errors of porphyrin metabolism.

Because of right leg weakness and pain, a computed tomography scan of the pelvis was done in February 1983, revealing multiple lytic lesions of the bony pelvis and proximal right femur with involvement of soft tissue. An open biopsy of the right iliac wing showed an angiosarcoma. A stain for factor VIII associated antigen was positive. The patient died in September 1984 as a result of this tumour.

Between August 1982 and December 1983 the patient lost 66 pounds. During this time he reported that he developed an acneiform rash on his face. On examination in December 1983 he had numerous open comedones and comedonal cysts over both malar crescents, periorbital crow's feet, and over the sides of the nose with blackheads, cobblestoning, and cysts. He also had several open comedones behind both ears. A skin biopsy showed actinically damaged skin with mild epithelial dysplasia, prominent solar elastosis, and increased mucinous deposition within the dermal connective tissue. There were also multiple comedones, most of which were associated with large sebaceous units. Comedones seemed to be loosely packed with keratin and a variety of organisms. Electron micrographs showed normal superficial and follicular epithelium and normal sebaceous glands, which contained large sebaceous cells with fat globules. There were no photomicrographs that included portions of a comedone. Although the patient did not recall a history of acne in earlier years or in childhood, his daughters reported that he had blackheads and pimples under his eyes as early as April 1972.

The patient worked driving a truck within St Louis from 1962 to January 1981 for a truck terminal that was subsequently found to be contaminated with TCDD. Analysis of soil samples at the site conducted by the United States Environmental Protection Agency in early 1983, about 10 years after spraying, showed concentrations of TCDD up 
to 17 parts per billion. This site was one of several truck terminals in St Louis believed to have been contaminated with TCDD by the application of waste oil for dust control. The contaminated oil was applied by a single company. Workers at the site reported that the terminal lot was covered with oil, leaving large pools in the lot after spraying. The contaminated oil is thought to have been applied during the early 1970s, although the exact dates this terminal was sprayed with TCDD are not known. During this period the patient recalled spending two to three months each year working on the terminal lot as a "spotter", a worker who hooks and unhooks trailers from trucks in the sprayed area of the terminal. He reported that his feet, legs, hands, and arms often became covered with oil from the terminal lot while doing this job. He had to have a separate pair of boots for this work. Also, the patient worked as a driver making pick ups and deliveries to the terminal one to three times daily. He continued to work as a driver and, intermittently, to work in the terminal lot into early 1980, during which time he may have had exposure to TCDD bound to dust. The patient probably had less exposure at this time, because heavy truck traffic in the lot would have resulted in decreasing dioxin concentration in years subsequent to its application. There was no history of exposure to herbicides, fungicides, other halogenated aromatics, or to oestrogens.

A sample of adipose tissue sent to a private laboratory was anecdotally reported first as without TCDD, then as positive. Despite repeated inquiries, no written report was ever provided by the laboratory.

\section{Discussion}

The constellation in this patient of soft tissue sarcoma, porphyria cutanea tarda, and probably chloracne, three rare conditions previously associated with exposure to TCDD, is striking, particularly in view of the patient's potentially heavy exposure to TCDD. It is highly unlikely that these three illnesses would coincide by chance alone. The annual age adjusted incidence of soft tissue sarcoma in the general population of the United States is only $5 \cdot 6 / 100000 .^{9}$ It has been suggested that the prevalence of porphyria cutanea tarda is only $1 / 25000 .^{10}$ This patient was one of only two workers (of 328 who participated in a survey of truck terminal workers) who had a skin condition suggestive of chloracne. Chloracne is considered pathognomic of exposure to certain halogenated hydrocarbons, among which TCDD is the most potent. This case suggests that the clinical manifestations of porphyria cutanea tarda and the recurrence of chloracne may occur with a latency of many years after exposure to TCDD.
Convincing evidence for a causal relation between TCDD exposure and soft tissue sarcoma comes from a cohort mortality study of United States chemical plant workers exposed to TCDD. ${ }^{11}$ A standardised mortality ratio (SMR) of 338 for soft tissue sarcoma was found (SMR 922 in the group with over 20 years of latency). Another large cohort mortality study of workers exposed to phenoxy herbicides and chlorophenols also showed a twofold increased risk of soft tissue sarcoma, which increased to a ninefold statistically significant risk when the analysis was restricted to sprayers, but which was not specifically associated with exposure to those herbicides most likely to have been contaminated with TCDD. ${ }^{12}$ Case-control studies conducted in northern, central, and southern Sweden have shown a two to sixfold increase in the risk of death from soft tissue sarcoma, primarily among workers with histories of occupational exposures to TCDD contaminated phenoxy acid herbicides or chlorophenols. $^{2}$ It has been suggested that the absence of a consistently increased risk in other case-control studies may depend on differences in genetic susceptibility for different groups, in amounts of TCDD contaminants in the pesticides, or in intensity of exposure because of differences in the spray seasons in different parts of the world. ${ }^{13}$ Other epidemiological studies have been inconclusive because of poor characterisation of exposure, inadequate latency, or small study populations and consequent low statistical power.

This worker's peak exposure to TCDD would have occurred eight to 10 years before his first recorded visit to a physician for porphyria cutanea tarda. Although in previous reports porphyria cutanea tarda among heavily exposed workers occurred near the time of exposure, ${ }^{1415}$ the metabolic defect can be long lasting. Persistent uroporphyrinuria was seen in one worker previously exposed to TCDD and affected with porphyria cutanea tarda about six years earlier. ${ }^{16}$ Several workers previously exposed in another factory, who had normal urinary porphyrins, had liver tissue fluorescence suggestive of hepatic porphyria. ${ }^{17}$ Persistent porphyrinuria was seen after 30 years in some workers who developed porphyria from exposure to hexachlorobenzene, another environmental contaminant capable of causing porphyria cutanea tarda. ${ }^{18}$ In rodents hepatic porphyria induced by TCDD persisted for at least six half lives after dosing with TCDD ended, and one animal first developed uroporphyrinuria only after dosing stopped. ${ }^{19}$

Porphyria cutanea tarda occurs when there is pronounced deficiency of uroporphyrinogen decarboxylase in the liver, and leads to increased excretion of uroporphyrin (8-carboxylate porphyrin), 7-carboxylate porphyrin, 6-carboxylate porphyrin, 5-carboxylate porphyrin, and isocoproporphyrins. 
The finding of increased faecal isocoproporphyrins (formed from excess 5-carboxylate porphyrinogen by the action of coproporphyrinogen oxidase, another haem pathway enzyme) is definitive evidence for a deficiency of hepatic uroporphyrinogen decarboxylase. ${ }^{20}$ Multiple environmental factors can contribute to clinical expression in all forms of porphyria cutanea tarda. In this patient, for example, alcohol consumption and other chemicals that may have been in the contaminated oil could have contributed. Erythrocyte uroporphyrinogen decarboxylase activity was normal in the patient and in his first degree relatives, which indicates that he did not have the inherited (autosomal dominant) form of porphyria cutanea tarda known as type II. ${ }^{21}$

The distribution of open and closed comedones at the time of examination in 1983 (behind the ears and over the malar areas) is characteristic of mild chloracne. ${ }^{22}$ Although this patient did not remember acneiform lesions before 1983, he was reported by his daughters to have had them as early as 1972 (during the time he would likely have been most exposed to TCD contaminated waste oil). Almost half of workers who have had chloracne have been found to have residual blackheads and recurring cysts up to 10 years after the workers considered themselves clear of disease. ${ }^{22}$ It has been suggested that this continued appearance of lesions after exposure has ceased may result from release of TCDD from fat. ${ }^{1}$ In this patient chloracne would have been likely to recur during 1983 as a result of mobilisation of TCDD from fat during the massive tumour induced weight loss this patient experienced. Mobilisation and concentration of TCDD during weight loss in monkeys ${ }^{23}$ and acute toxicity as a result of starvation induced mobilisation of chlorinated hydrocarbon insecticides from fat in rodents are animal models for this effect. ${ }^{24}$ Although the histopathological appearance of the biopsy was suggestive of solar elastosis in an acne prone individual, the differentiation from chloracne based on histopathological criteria alone is difficult. ${ }^{1}$ Skin biopsy is less sensitive than clinical examination of skin in the diagnosis of residual chloracne. ${ }^{25} \mathrm{~A}$ biopsy reflects a small sample, and solar elastosis has been reported to be more common and more severe among workers with chloracne from TCDD. ${ }^{26}$

This case supports the aetiological relation between environmental exposure to TCDD and the subsequent development of soft tissue sarcoma and porphyria cutanea tarda. It suggests that porphyria cutanea tarda and the recurrence of chloracne may occur with a latency of many years after exposure to TCDD.

We thank Shigeru Sassa, MD, PhD, Rockefeller University Hospital, New York, New York, for determination of erythrocyte uroporphyrinogen decarboxylase and for urine porphyrin fractionation.

This study was supported in part by the National Institute for Occupational Safety and Health (NIOSH) of the Centers for Disease Control and by NIOSH grant $1 \mathrm{~K} 01 \mathrm{OH} 00123-01$.

1 Taylor JS. Environmental chloracne: update and overview. Ann NY Acad Sci 1979;320:294-307.

2 United States Environmental Protection Agency. Health assessment document for polychlorinated dibenzo-p-dioxins. Cincinnati, Ohio: USEPA 1985, (EPA/600/8-84/014E).

3 Van Miller JP, Lalich JJ, Allen JR. Increased incidence of neoplasms in rats exposed to low levels of $2,3,7,8$-tetrachlorodibenzo-p-dioxin. Chemosphere 1977;9:537-44.

4 National Institute for Occupational Safety and Health. 2, 3, 7, 8-tetrachlorodibenzo-p-dioxin (TCDD, "dioxin"). Current Intelligence Bulletin 40. Cincinnati US Department Health and Human Services DHHS (NIOSH) Publication No 84-104, 1984.

5 Carter CD, Kimbrough RD, Liddle JA, Cline RE, Zack MM. Tetrachlorodibenzodioxin: an accidental poisoning episode in horse arenas. Science 1975;188:738-40.

6 Patterson DG, Hoffman RE, Needham LL, Roberts DW, Bagby JR, Pirkle JL, et al. 2, 3, 7, 8-tetrachlorodibenzo-pdioxin levels in adipose tissue of exposed and control persons in Missouri. fAMA 1986;256:2683-6.

7 Hoffman RE, Stehr-Green PA, Webb KB, Evans G, Knutsen AP, Schramm WF, et al. Health effects of long -term exposure to $2,3,7,8$-tetrachlorodibenzo-p-dioxin. $\mathcal{F} A M A$ 1986;255:2031-8.

8 Hope W. Lischwe D, Russell W, Weiss S. Porphyria cutanea tarda and sarcoma in a worker exposed to $2,3,7,8$-Tetrachlorodibenzodioxin-Missouri. Morbidity and Mortality weekly report 1984;33:113-4.

9 Hoar Zahm S, Tucker MA, Fraumeni JF. Soft tissue sarcoma. In: Schottenfeld D, Fraumeni JF, eds. Cancer epidemiology and prevention. London: Oxford University Press (in press).

10 Bickers DR. The dermatologic manifestations of human porphyria. Ann NY Acad Sci 1987;514:261-7.

11 Fingerhut MA, Halperin WE, Marlow DA, Piacitelli LA, Honchar PA, Sweeney MH, et al. Cancer mortality in workers exposed to 2, 3, 7, 8-tetrachlorodibenzo-p-dioxin. New Engl f Med 1991;324:212-8.

12 Saracci R, Kogevinas M, Bertazzi P, Bueno de Mesquita BH, Coggon D, Green LM, et al. Cancer mortality in workers exposed to chlorophenoxy herbicides and chlorophenols. Lancet 1991;338:1027-32.

13 Woods JS, Polissar L, Severson RK, Heuser LS, Kulander BG. Soft tissue sarcoma and non-Hodgkin's lymphoma in relation to phenoxyherbicide and chlorinated phenol exposure in Western Washington. F Natl Cancer Inst 1987; 78:899-909.

14 Bleiberg J, Wallen M, Brodkin R, Applebaum IL. Industrially acquired porphyria. Archives of Dermatology 1964;89:793-7.

15 Pazderova-Vejlupkova J, Nemcova M, Pickova J, Jirasek L, Lukas $\mathrm{E}$. The development and prognosis of chronic intoxication by tetrachloridibenzo-p-dioxin in men. Arch Environ Health 1981;36:5-11.

16 Poland AP, Smith D, Metter G, Possick P. A health survey of workers in a 2, 4-D and 2, 4, 5-T Plant. Arch Environ Health 1971;22:316-27.

17 Pazderova-Vejlupkova J, Lukas E, Nemcova M, Pickova J, Jirasek L. Chronic poisoning by 2, 3, 7, 8-tetrachlorodibenzo-p-dioxin (translation). Pracov Lek 1980;32:204-9.

18 Cripps DJ, Peters HA, Gocmen A, Dogramici I. Porphyria turcica due to hexachlorobenzene: A 20 to 30 year followup study on 204 patients. Br $\mathcal{F}$ Dermatol 1984;111:413-22.

19 Goldstein JA, Linko P, Bergman H. Induction of porphyria in the rat by chronic versus acute exposure to $2,3,7,8$-tetrachlorodibenzo-p-dioxin. Biochem Pharmacol 1982;31: 1606-13

20 Elder GH. Porphyrin metabolism in porphyria cutanea tarda. Semin Hematol 1977;14:227-42. 
21 Held JL, Sassa S, Kappas A, Harber LC. Erythrocyte uroporphyrinogen decarboxylase activity in porphyria cutanea tarda - a study of 40 consecutive patients. F Invest Dermatol $1989 ; 93: 332-4$.

22 Crow KD. Chloracne. Transactions of St fohn's Hospital Dermatological Society 1970;56:79-90.

23 McNulty WP, Nielsen-Smith KA, Lay JO, Lippstreu DL, Kangas NL, Lyon PA, Gross ML. Persistence of TCDD in monkey adipose tissue. Fd Chem Toxic 1982;20:985-987.

24 Hayes WJ, Laws ER. Handbook of pestcide toxicology. New York: Academic Press, 1991; 734.

25 Moses M. Prioleau PG. Cutaneous histologic findings in chemical workers with and without chloracne with past exposure to 2, 3, 7, 8-tetrachlorodibenzo-p-dioxin. f $\mathrm{Am}$ Acad Dermatol 1985;12:497-506.

26 Suskind RR, Hertzberg VS. Human health effects of 2, 4, 5-T and its toxic contaminants. $\mathscr{F} A M A 1984 ; 251: 2372-80$.

27 Schwartz S, Edmondson P, Stephenson B, Sarkar D, Freyholtz H. Direct spectrofluorophotometric determina- tion of porphyrin in diluted urine. Annals of Clinical Research 1976;8:156-61.

28 Chiba M, Sassa S. Analysis of porphyrin carboxylic acids in biological fluids by high performance liquid chromatography. Anal Biochem 1982;124:279-85.

29 Sassa S, de Verneuil H, Anderson KE, Kappas A. Purification and properties of human erythrocyte uroporphyrinogen decarboxylase: immunological demonstration of the enzyme defect in porphyria cutanea tarda. Trans Assoc Am Physicians 1983;96:65-75.

30 Rimington C. Investigation of porphyria. Qualitative tests. Association of Clinical Pathologists Broadsheet No 20. November, 1958.

31 Smith SG. The use of thin layer chromatography in the separation of free porphyrins and porphyrin methyl esters. $B r \mathcal{F}$ Dermatol 1975;93:291-5.

Accepted 8 February 1993

\section{Correspondence and editorials}

The British fournal of Industrial Medicine welcomes correspondence relating to any of the material appearing in the journal. Results from preliminary or small scale studies may also be published in the correspondence column if this seems appropriate. Letters should be not more than 500 words in length and contain a minimum of references. Table and figures should be kept to an absolute minimum. Letters are accepted on the understanding that they may be subject to editorial revision and shortening.

The journal now also publishes editorials which are normally specially commissioned. The Editor welcomes suggestions regarding suitable topics; those wishing to submit an editorial, however, should do so only after discussion with the Editor. 